\title{
Climate economics for the masses
}

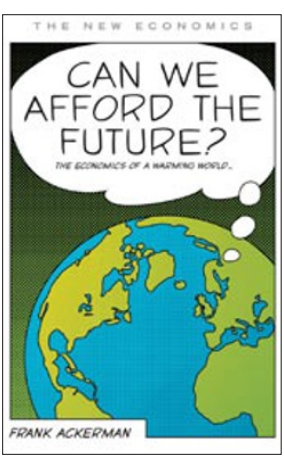

\section{CAN WE AFFORD THE FUTURE?: THE ECONOMICS OF A WARMING WORLD}

\author{
by Frank Ackerman
}

Zed Books: 2008. 160pp. £12.99

\section{A layman's guide to climate economics leaves the average reader unable to distinguish mainstream theory from heterodoxy.}

Whose fault is it that our species has so far failed to take serious action on climate change? One group of suspects - neoclassical economists, that dismal subspecies Homo economicus for whom human interest stories hold no appeal - is fingered in Frank Ackerman's latest offering, Can We Afford the Future?: The Economics of a Warming World.

A research economist at

Tufts University in Massachusetts who spends most of his time berating mainstream economists for failing to protect the environment, Ackerman sets out here to call for a new kind of economics that does a better job of preserving the future. In doing so, Ackerman becomes a perfect odd-couple match for Bjørn Lomborg, the Danish political scientist whose sky-is-not-falling perspective was expressed recently in Cool It: The Skeptical Environmentalist's Guide to Global Warming. Reading both books together provides conclusive evidence that the bumper-sticker culture of cable TV news has finally reached that mostly unlikely and impenetrable of topics: the economics of climate change.

Lest the reader think I am being unfair, let me emphasize that the bumper stickers come from Ackerman himself, who devotes the majority of this book to his four favorites. First up is the dictum

"Your grandchildren's lives are important", which critiques the economic practice of 'discounting' future costs and benefits by giving them less weight than present-day costs and benefits; followed by "We need to buy insurance for the planet", which argues that our thinking about climate change should be dominated by a desire to avoid worst-case scenarios. Next in line is "Climate damages are too valuable to have prices", which concludes that economists' efforts to extend cost-benefit analysis by estimating prices for non-market commodities such as nature and human life "have produced ludicrous results"; and finally, "Some costs are better than others", which basically argues - and I honestly can't tell if this is a legitimate description or neoclassical snark - that a dollar is not a dollar. Like most bumper stickers, these are overly simplistic - do you know anyone who doesn't value their grandchildren? - but nonetheless they are good focal points for debate.

The high point of the book is Ackerman's explanation of the recent work by Harvard economist Martin Weitzman on situations in which truly catastrophic outcomes - such as a $6{ }^{\circ} \mathrm{C}$ rise in global temperatures this century - are unlikely but not impossible. Weitzman is a good bet to win the Nobel Prize for his pioneering contributions to environmental economics, and his work deserves more public attention. Conversely, the low point of the book is Ackerman's take-down of Lomborg, whose work already gets plenty of public attention.

Although it is hard to be neutral about anything involving Lomborg, you don't have to be partisan to conclude that Ackerman's treatment of Lomborg is unfair. The most egregious example is when Ackerman tears into Lomborg for arguing that a US\$1 carbon tax will have economic costs of US\$11 billion and that a US\$30 carbon tax will have economic costs of US $\$ 7$ trillion. Ackerman scores rhetorical points on the obvious question:
"Why should a $\$ 30$ tax cost more than 600 times as much as a $\$ 1$ tax?" But as a Harvard-trained economist he should know better: a well-known rule of thumb in economics - search "Harberger triangle" if you care to know more - is that the economic cost associated with a tax rises with the square of the tax rate, meaning that a US\$30 tax could reasonably cost 900 times more than a US $\$ 1$ tax. Ackerman completely overlooks this point, choosing instead to compound his mistake by spending a paragraph erroneously mocking Lomborg for having "just one short, ambiguous" endnote on this subject.

As the above example illustrates, the general reader will encounter a nearly impossible challenge with this book: untangling the parts that accurately portray mainstream economics from those are the author's heterodoxy. Ackerman sounds convincing when he says that "conventional economic theory reflexively shuns intervention in private markets" and is in thrall to the "fairy tale" of Adam Smith's invisible hand. But a very different picture comes from reading the "Economists' Statement on Climate Change", a call for action signed by six Nobel laureates way back in 1997, or from learning that Harvard's Gregory Mankiw, an economist with impeccable conservative credentials, has started a "Pigou Club" on Facebook to drum up support for carbon taxes. Interested readers could profitably go back even further, to Thomas Schelling's prescient 1992 address to the American Economic Association on "Some economics of global warming". 
Where Ackerman does differ sharply from mainstream economic thought is in his policy prescription. Instead of focusing, as almost all economists do, on carbon taxes or similar tools that seek to harness the power of capitalism and allow free-market competition to pick winning technologies, he advocates massive government-funded cleanenergy R\&D. US President-elect Barack Obama seems to be moving in this direction, and perhaps it will work, but the US government's ongoing love affair with environmentally questionable technologies such as corn-based ethanol and 'clean coal' is not encouraging. It doesn't help that Ackerman recommends focusing R\&D efforts on technologies that are "not hard to identify" but that are nonetheless not identified by him.

In the end, the best reason to purchase this book is to provide 'fair and balanced' companionship to Lomborg's Cool It. The two of them together come off like a high school debate contest: full of facts, most of them true, but in the end too biased to provide much enlightenment.

Published online: 15 January 2009

doi:10.1038/climate.2009.4

Yoram Bauman

Yoram Bauman is an economist who teaches at the University of Washington and performs stand-up comedy. e-mail:yoram@standupeconomist.com

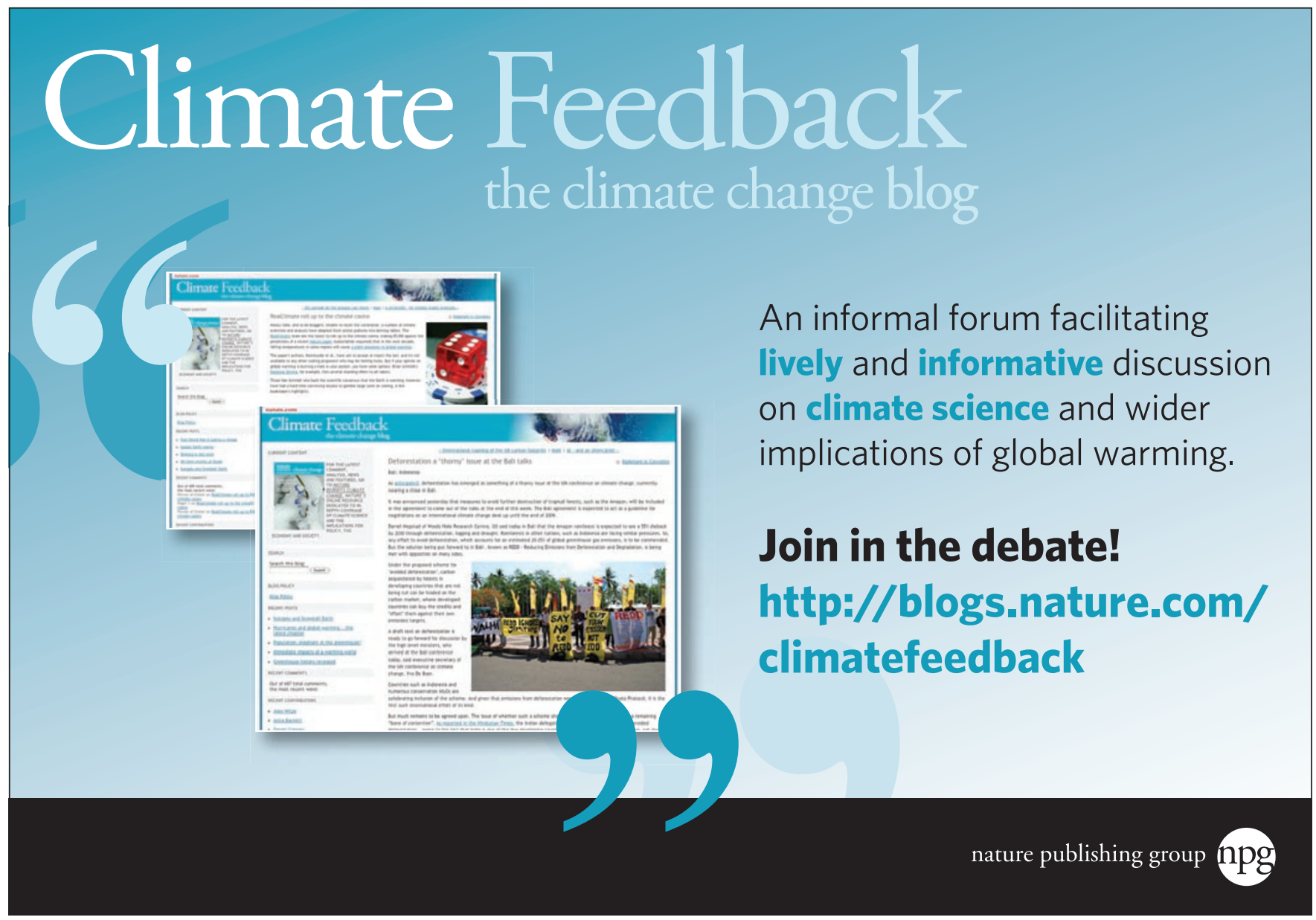

